\title{
Identification of sustainability of road safety improvement in Russian cities with a population of more than 1 million people
}

\author{
Artur Petrov ${ }^{1, *}$ \\ ${ }^{1}$ Tyumen Industrial University, Melnikaite street, 72-221, Tyumen, Russia
}

\begin{abstract}
The article examines the issues of assessing the sustainability of road safety improvement process in Russian cities with a population of more than 1 million people. In $2015 \ldots 2018$ a sharp decrease in the overall level of road traffic accidents in the Russian Federation was recorded. However, in different regions and cities of the country this positive process runs extremely heterogeneously, with various speeds and different levels of qualitative changes in the field of road safety. The T-Wilcoxon criterion is an instrument, used in analyzing accident rate statistics, which can help in the argumentation of the opinion on the sustainability of this process or, vice versa, on the chaotic state and weak expression. On the example of accident rate statistics in Russian cities with a population of more than 1 million people, the article proves that improvement of road safety can be characterized as sustainable.
\end{abstract}

\section{Introduction}

A significant decrease [1] in the number of road accidents, dead and injured people in road accidents in the last four years (2018/2015) in Russia is the cause for the formulation of general conclusion about the success of road safety Federal Program realization. How stable is this positive trend? Whether everywhere the process of road safety improvement can be considered as qualitative? To answer these questions, we will use the T-Wilcoxon criterion.

\section{Methods of assessment of researched process stability}

T-Wilcoxon criterion is designed to compare two dependent samples between themselves regarding the attribute expression [2-12]. Particularly, with its help, it is possible to determine the degree of changes intensity in dependent selections at different time periods. $\mathrm{T}$-criterion is based on the ranking of the absolute values of the difference between two sets of sample values in the first and second experiments. In our case, the data sets for 2018 and 2015 will be compared by two most important characteristics of road traffic accidents

\footnotetext{
* Corresponding author: ArtIgPetrov@yandex.ru
} 
(Human Risk $H R$ and Road Traffic Accident Severity Coefficient $C_{s e v . R T A}$ ) in Russian cities with a population of more than 1 million people.

Zero hypothesis of the research $\mathrm{H}_{0}$ usually $[3,5]$ formulated as «Intensity of shifts in the typical direction doesn't exceed the intensity of shifts in the atypical direction». Applied to our case, it consists in the absence of statistical differences between the time distributions defined for the same selections of 2015 and 2018. According to the zero hypothesis, differences between selections values of different years of research are not enough to accept that non-random factors cause this difference.

Hypothesis $\mathrm{H}_{1}$ classically [3,5] formulated as «Intensity of shifts in the typical direction exceeds the intensity of shifts in the atypical direction», i.e. the change in the data distribution on the characteristics of the accident rate of 2018, relative to similar data distribution of 2015, did not occur accidentally - some specific factors had an impact on this data shift, e.g. organizational and managerial efforts that were invested in the solution of increasing road safety problem.

The essence of the research is to prove hypothesis $\mathrm{H}_{1}$ and refute zero hypothesis $\mathrm{H}_{0}$. Two results are possible. In the case of the hypothesis $\mathrm{H}_{1}$ evidence, it is necessary to conclude the non-randomness of the shift and the effectiveness of some managerial influence, aimed at changing the actual situation in the sphere of road safety. If hypothesis $\mathrm{H}_{1}$ is not proved, i.e. the zero hypothesis $\mathrm{H}_{0}$ will be confirmed, then it can be claimed that the quality of the road safety management leaves much to be desired. When using the methods of mathematical statistics, level of statistical significance p-level, in other words, «probability that we found differences as significant, but they are actually accidental», plays an important role [8]. In statistics, three levels of statistical significance are distinguished: the lowest $(5 \%$ or $p=0.05)$; sufficient $(1 \%$ or $p=0.01)$ and the highest $(0.1 \%$ or $p=0.001)$. If the probability of randomness of received results is more than $5 \%(p$ $=0.05)$, then the lowest level of statistical significance is not reached, and hypothesis $\mathrm{H}_{1}$ is not proved.

\section{Used road safety statistics}

To study the quality of road safety improvement process comparisons between two sets of data about road accidents with victims (2015 and 2018) were made in Russian cities with a population of more than 1 million people (totally 15 cities). The initial information was received on the website of the State Inspection for Road Traffic Safety of the Ministry of Internal Affairs of Russia [1].

Tables 1 and 2 shows the initial (for the Russian cities with a population of more than 1 million people) information, necessary for calculation values of such significant characteristics of accident rate [6,7] as Human Risk $H R$ and Road Traffic Accident Severity Coefficient $C_{\text {Sev. }}$ RTA.

Table 1. Characteristics (2015) of road accident rate in Russian cities with a population of more than 1 million people.

\begin{tabular}{|c|c|c|c|c|c|c|c|}
\hline \multirow[b]{3}{*}{$\begin{array}{c}\text { Russian cities } \\
\text { with a } \\
\text { population } \\
\text { of more than } \\
1 \text { million people }\end{array}$} & \multicolumn{7}{|c|}{ Numerical values } \\
\hline & \multicolumn{5}{|c|}{ Amount (2015) [1] } & \multirow[b]{2}{*}{$\begin{array}{c}H R, \\
\text { deaths } \\
/ \\
100 \mathrm{~K} \\
\text { people }\end{array}$} & \multirow[b]{2}{*}{$\begin{array}{l}C_{S e v} . \\
R T A\end{array}$} \\
\hline & 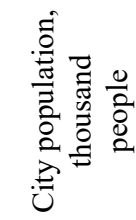 & 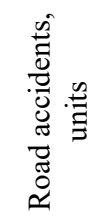 & 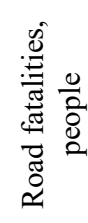 & 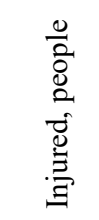 & 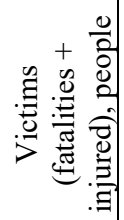 & & \\
\hline Moscow & 12197596 & 10396 & 673 & 11903 & 12576 & 5.52 & 5.35 \\
\hline
\end{tabular}




\begin{tabular}{|l|c|c|c|c|c|c|c|}
\hline St. Petersburg & 5191690 & 7243 & 354 & 8512 & 8866 & 6.82 & 3.99 \\
\hline Novosibirsk & 1567087 & 1762 & 79 & 2012 & 2091 & 5.04 & 3.78 \\
\hline Ekaterinburg & 1428042 & 1014 & 91 & 1285 & 1376 & 6.37 & 6.61 \\
\hline $\begin{array}{l}\text { Nizhny } \\
\text { Novgorod }\end{array}$ & 1267760 & 2072 & 71 & 2509 & 2580 & 5.60 & 2.75 \\
\hline Kazan & 1205651 & 1970 & 66 & 2261 & 2327 & 5.47 & 2.84 \\
\hline Chelyabinsk & 1183387 & 1962 & 87 & 2391 & 2478 & 7.35 & 3.51 \\
\hline Omsk & 1173854 & 2591 & 94 & 3157 & 3251 & 8.01 & 2.89 \\
\hline Samara & 1171820 & 1125 & 79 & 1380 & 1459 & 6.74 & 5.41 \\
\hline Rostov-on-don & 1114806 & 1725 & 72 & 2136 & 2208 & 6.46 & 3.26 \\
\hline Ufa & 1105667 & 1916 & 66 & 2409 & 2475 & 5.97 & 2.67 \\
\hline Krasnoyarsk & 1052218 & 1904 & 77 & 2193 & 2270 & 7.32 & 3.39 \\
\hline Voronezh & 1023570 & 1160 & 105 & 1356 & 1461 & 10.26 & 7.19 \\
\hline Perm & 1036469 & 2092 & 100 & 2547 & 2647 & 9.65 & 3.78 \\
\hline Volgograd & 1017451 & 1032 & 87 & 1195 & 1282 & 8.55 & 6.79 \\
\hline
\end{tabular}

Table 2. Characteristics (2018) of road accident rate in Russian cities with a population of more than 1 million people.

\begin{tabular}{|c|c|c|c|c|c|c|c|}
\hline \multirow[b]{3}{*}{$\begin{array}{c}\text { Russian cities } \\
\text { with a } \\
\text { population } \\
\text { of more than } \\
1 \text { million people }\end{array}$} & \multicolumn{7}{|c|}{ Numerical values } \\
\hline & \multicolumn{5}{|c|}{ Amount (2018) [1] } & \multirow[b]{2}{*}{$\begin{array}{c}H R, \\
\text { deaths } \\
/ \\
100 \mathrm{~K} \\
\text { people }\end{array}$} & \multirow[b]{2}{*}{$\begin{array}{l}C_{s e v} \\
\text { RTA. }\end{array}$} \\
\hline & 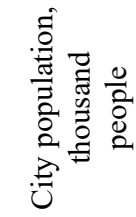 & 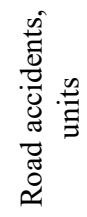 & 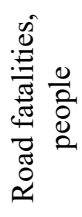 & 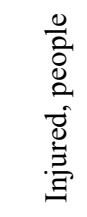 & 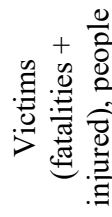 & & \\
\hline Moscow & 12615882 & 9151 & 465 & 10469 & 10934 & 3.69 & 4.25 \\
\hline St. Petersburg & 5383890 & 6463 & 232 & 7693 & 8157 & 4.31 & 2.84 \\
\hline Novosibirsk & 1618039 & 1463 & 80 & 1807 & 1887 & 4.94 & 4.24 \\
\hline Ekaterinburg & 1483119 & 978 & 61 & 1254 & 1315 & 4.11 & 4.64 \\
\hline $\begin{array}{l}\text { Nizhny } \\
\text { Novgorod }\end{array}$ & 1253511 & 2312 & 62 & 2700 & 2762 & 4.95 & 2.24 \\
\hline Kazan & 1251969 & 2030 & 49 & 2351 & 2400 & 3.91 & 2.04 \\
\hline Chelyabinsk & 1200719 & 1772 & 72 & 2229 & 2301 & 6.00 & 3.13 \\
\hline Omsk & 1164815 & 2300 & 77 & 2870 & 2947 & 6.61 & 2.61 \\
\hline Samara & 1156608 & 1404 & 44 & 1681 & 1725 & 3.80 & 2.55 \\
\hline Rostov-on-don & 1133307 & 1270 & 57 & 1545 & 1602 & 5.03 & 3.56 \\
\hline Ufa & 1124226 & 1936 & 61 & 2412 & 2473 & 5.43 & 2.47 \\
\hline Krasnoyarsk & 1095286 & 1528 & 46 & 1699 & 1745 & 4.20 & 2.64 \\
\hline Voronezh & 1054111 & 1176 & 64 & 1467 & 1531 & 6.07 & 4.18 \\
\hline Perm & 1053934 & 1486 & 42 & 1798 & 1840 & 3.99 & 2.28 \\
\hline Volgograd & 1013468 & 1093 & 61 & 1402 & 1463 & 6.02 & 4.17 \\
\hline
\end{tabular}

\section{Results of calculation of Wilcoxon T-critrion for researched data sets}

Tables 3 and 4 show results of T-Wilcoxon criterion assessment [10] relatively changes of Human Risk $H R$ and Road Traffic Accident Severity Coefficient $C_{\text {sev. } R T A \text {. values in Russian }}$ cities with a population of more than 1 million people during 2015-2018 «Increasing of value» is taken as an atypical shift. 
Table 3. Calculations of atypical shifts ranks sum $T_{\text {emp. (2018/2015) }}$ relative to characteristic of Human Risk $H R$ in Russian cities with a population of more than 1 million people.

\begin{tabular}{|l|c|c|c|c|c|}
\hline \multirow{2}{*}{$\begin{array}{c}\text { Russian cities } \\
\text { with a population } \\
\text { of more than } \\
\text { 1 million people }\end{array}$} & \multicolumn{2}{|c|}{$\begin{array}{c}\text { Values of } H R, \\
\text { deaths/100 K people }\end{array}$} & \multicolumn{2}{|c|}{ Shift of $H R$} & \multirow{2}{*}{$\begin{array}{c}\text { Ranked } \\
\text { number } \\
\text { of shift }\end{array}$} \\
\cline { 2 - 5 } & $\begin{array}{c}\text { Before } \\
(2015)\end{array}$ & $\begin{array}{c}\text { After } \\
(2018)\end{array}$ & Factual & Absolute & 8 \\
\hline Moscow & 5.52 & 3.69 & -1.83 & 1.83 & 10 \\
\hline St. Petersburg & 6.82 & 4.31 & -2.51 & 2.51 & 1 \\
\hline Novosibirsk & 5.04 & 4.94 & -0.10 & 0.10 & 9 \\
\hline Ekaterinburg & 6.37 & 4.11 & -2.26 & 2.26 & 3 \\
\hline Nizhny Novgorod & 5.60 & 4.95 & -0.65 & 0.65 & 7 \\
\hline Kazan & 5.47 & 3.91 & -1.56 & 1.56 & 4 \\
\hline Chelyabinsk & 7.35 & 6.00 & -1.35 & 1.35 & 4 \\
\hline Omsk & 8.01 & 6.61 & -1.40 & 1.40 & 5 \\
\hline Samara & 6.74 & 3.80 & -2.94 & 2.94 & 12 \\
\hline Rostov-on-don & 6.46 & 5.03 & -1.43 & 1.43 & 6 \\
\hline Ufa & 5.97 & 5.43 & -0.54 & 0.54 & 2 \\
\hline Krasnoyarsk & 7.32 & 4.20 & -3.12 & 3.12 & 13 \\
\hline Voronezh & 10.26 & 6.07 & -4.19 & 4.19 & 14 \\
\hline Perm & 9.65 & 3.99 & -5.66 & 5.66 & 15 \\
\hline Volgograd & 8.55 & 6.02 & -2.53 & 2.53 & 11 \\
\hline Atypical shifts ranks sum Temp. & \multicolumn{5}{l|}{} \\
\hline
\end{tabular}

Table 4. Calculations of atypical shifts ranks sum Temp. (2018/2015)relative to characteristic of Road Traffic Accident Severity Coefficient $C_{s e v . R T A}$. in Russian cities with a population of more than 1 million people.

\begin{tabular}{|c|c|c|c|c|c|}
\hline \multirow{2}{*}{$\begin{array}{c}\text { Russian cities } \\
\text { with a population } \\
\text { of more than } \\
1 \text { million people }\end{array}$} & \multicolumn{2}{|c|}{$\begin{array}{l}\text { Values of } C_{\text {sev. } R T A .,} \\
\text { deaths/100 K people }\end{array}$} & \multicolumn{2}{|c|}{ Shift of $C_{\text {sev. }} R T A$. } & \multirow{2}{*}{$\begin{array}{l}\text { Ranked } \\
\text { number } \\
\text { of shift }\end{array}$} \\
\hline & $\begin{array}{l}\text { Before } \\
(2015)\end{array}$ & $\begin{array}{l}\text { After } \\
(2018)\end{array}$ & Factual & Absolute & \\
\hline Moscow & 5.35 & 4,25 & -1.10 & 1.10 & 9 \\
\hline St. Petersburg & 3,99 & 2,84 & -1.15 & 1.15 & 10 \\
\hline Novosibirsk & 3,78 & 4,24 & 0.46 & 0.46 & 5 \\
\hline Ekaterinburg & 6,61 & 4,64 & -1.97 & 1.97 & 12 \\
\hline Nizhny Novgorod & 2,75 & 2,24 & -0.51 & 0.51 & 6 \\
\hline Kazan & 2,84 & 2,04 & -0.80 & 0.80 & 8 \\
\hline Chelyabinsk & 3,51 & 3,13 & -0.38 & 0.38 & 4 \\
\hline Omsk & 2,89 & 2,61 & -0.28 & 0.28 & 2 \\
\hline Samara & 5,41 & 2,55 & -2.86 & 2.86 & 14 \\
\hline Rostov-on-don & 3,26 & 3,56 & 0.30 & 0.30 & 3 \\
\hline Ufa & 2,67 & 2,47 & -0.19 & 0.19 & 1 \\
\hline Krasnoyarsk & 3,39 & 2,64 & -0.75 & 0.75 & 7 \\
\hline Voronezh & 7,19 & 4,18 & $-3,01$ & 3,01 & 15 \\
\hline Perm & 3,78 & 2,28 & -1.50 & 1.50 & 11 \\
\hline Volgograd & 6,79 & 4,17 & -2.61 & 2.62 & 13 \\
\hline \multicolumn{5}{|c|}{ Atypical shifts ranks sum $T_{\text {emp. }}$. } & 8 \\
\hline
\end{tabular}

Atypical shifts ranks sum (in tables 4 positive shifts are atypical) is formed during the process of summation of ranked numbers specific for positive shifts cases. The procedure of making decisions about detection of shifts or statistically significant differences between selections of 2015 and 2018 consists in the comparison of atypical shifts ranks sum values $\mathrm{T}_{\text {emp. with tabular values }} \mathrm{T}_{\text {cr. }}$ Table 5 shows the fragment of the table of $\mathrm{T}$-Wilcoxon 
criterion critical values $\left(\mathrm{T}_{\mathrm{cr}}\right)$ for two levels of statistical significance. Reasoning can be based on the results of comparison $\mathrm{T}_{\text {emp. }}$ with $\mathrm{T}_{\text {cr. }}(\mathrm{p}=0.01)[2,3,4,5,8,9,12]$.

Table 5. The fragment of table of T-Wilcoxon criterion critical values $\left(\mathrm{T}_{\mathrm{cr} .}\right)$ [8].

\begin{tabular}{|c|c|c|c|c|c|}
\hline \multirow{2}{*}{$\mathrm{n}$} & \multicolumn{2}{|c|}{$\begin{array}{c}\text { Level of statistical } \\
\text { significance }\end{array}$} & \multirow{2}{*}{$\mathrm{n}$} & \multicolumn{2}{c|}{$\begin{array}{c}\text { evel of statistical } \\
\text { significance }\end{array}$} \\
\cline { 2 - 3 } \cline { 6 - 6 } & $\mathrm{p}=0.05$ & $\mathrm{p}=0.01$ & & $\mathrm{p}=0.05$ & $\mathrm{p}=0.01$ \\
\hline 5 & 0 & - & 13 & 21 & 12 \\
\hline 6 & 2 & - & 14 & 25 & 15 \\
\hline 7 & 3 & 0 & $\mathbf{1 5}$ & $\mathbf{3 0}$ & $\mathbf{1 9}$ \\
\hline 8 & 5 & 1 & 16 & 35 & 23 \\
\hline 9 & 8 & 3 & 17 & 41 & 27 \\
\hline 10 & 10 & 5 & 18 & 47 & 32 \\
\hline 11 & 13 & 7 & 19 & 53 & 37 \\
\hline 12 & 17 & 9 & 20 & 60 & 43 \\
\hline
\end{tabular}

Rule of acceptance the hypothesis $H_{1}$ if the empirical value of criterion $T_{\text {emp. }} \leq T_{\text {cr. }}$, appropriate to the level of statistical significance $\mathrm{p}=0.01$, then promoted statistical hypothesis is considered to be proved $[2,3,4,5,8,9]$.

\section{Results of research}

Comparing the value of atypical shifts ranks sum $\mathrm{T}_{\text {emp. }}=0$ (for the case of $H R$ ) and $\mathrm{T}_{\text {emp. }}=8$ (for the case of $C_{\text {sev. RTA. }}$ ) with tabular ( $\mathrm{T}_{\text {cr. }}$ ) values of $\mathrm{T}$-Wilcoxon criterion $\left(\mathrm{T}_{\text {cr. }}=19\right.$ for the case $\mathrm{p}=0.01, \mathrm{~N}=30$ ) it can be concluded that $\mathrm{T}_{\text {emp. }}>\mathrm{T}_{\text {cr. }}$, i.e. $\mathrm{T}_{\text {emp. }}$ is not in the zone of significance and changes of values of $H R$ and $C_{S e v . R T A}$. are accidental and hypothesis $\mathrm{H}_{1}$ is not proved.

\section{Explanation of the results}

Studies [13] show that sharp improvement of level of traffic safety has become possible in Russian cities with a population of more than 1 million people because of increase in attention of the state to questions of people's life quality in recent years. The analysis of the process of transformation of living conditions of the people in the safety performance of traffic dedicated to the articles [14]. Articles [15] are devoted to assessment of spatial features of road and transport accident rate in regions of Russia. However, this trend is not typical for all Russian cities. The all-russian trend of improving road safety is not yet typical for the Far East and Siberia.

\section{Conclusion}

On the example of Russian cities with a population of more than 1 million people we draw a conclusion that process of road safety improvement is quite sustainable.

\section{References}

1. https://www.gibdd.ru/stat/

2. R. A. Donnelly (jr.), Statistics (Astrel-AST, Moscow, 2007)

3. I. I. Yeliseyeva, M. M. Yuzbashev, General theory of statistics (Finance and statistics, Moscow, 2004) 
4. E. A. Morozov, 2014 Scientific dialogue, 3(27), pp 29-45 (2014).

5. A. I. Orlov, Application-oriented statistics (Examination, Moscow, 2004)

6. A. I. Petrov, Peculiarities of the formation of the motor transport accident rate in space and time (Publishing house TSOGU, Tyumen, 2013)

7. A. I. Petrov, City. Transport. External environment. Stability of public transport in the conditions of adverse influence of the external environment (Publishing house TSOGU, Tyumen, 2013)

8. E. V. Sidorenko, Methods of mathematical processing in psychology: practical guidance (Publishing house «Speech», St. Petersburg, 2002)

9. Steady statistical methods of assessment of data (Publishing house «Mechanical engineering», Moscow, 1984)

10. F. Wilcoxon, Individual comparisons by ranking methods. Biometrics Bulletin, 1 (6), pp 80-83 (1945)

11. S. Siegel, Non-parametric statistics for the behavioral sciences (McGraw-Hill, New York, 1956)

12. O. G. Berestneva, O. V. Marukhina, G. E. Shevelev, Application of mathematical statistics (TPU, Tomsk, 2012)

13. A .I. Petrov, Economic and Social Changes-Facts Trends Forecast, 3(45), pp 154-172 (2016)

14. V. Kolesov, A. Petrov, Transportation Research Procedia 20, pp 305-310 (2017)

15. A. Petrov, D. Petrova, IOP Conf. Series: Materials Science and Engineering 142, 012116 (2016) 